\title{
Use of Saccharomyces cerevisiae-based products and effects on rumen environment and performance of sheep subjected to dietary changes
}

\section{Larissa Alt Tavares ${ }^{*}$ (i) Maria Carolina Narval de Araújo² (i) Antônio Amaral Barbosa ${ }^{2}$ (D) Cássio Cassal Brauner ${ }^{3}$ (i) Marcio Nunes Corrêa ${ }^{5}$ (i) Eduardo Schmitt $^{5}$ (D) Viviane Rohrig Rabassa ${ }^{5}$ (i) Francisco Augusto Burkert Del Pino ${ }^{6}$ (])}

${ }^{1}$ Programa de Pós-graduação em Biotecnologia, Universidade Federal de Pelotas (UFPel), 96160-000, Pelotas, RS, Brasil. E-mail: larissatav.21@gmail.com. "Corresponding author.

${ }^{2}$ Programa de Pós-graduação em Veterinária, Universidade Federal de Pelotas (UFPel), Pelotas, RS, Brasil.

${ }^{3}$ Departamento de Zootecnia, Faculdade de Agronomia Eliseu Maciel, Universidade Federal de Pelotas (UFPel), Pelotas, RS, Brasil.

${ }^{5}$ Departamento de Clínicas Veterinária, Faculdade de Veterinária, Universidade Federal de Pelotas (UFPel), Pelotas, RS, Brasil.

${ }^{6}$ Centro de Ciências Químicas, Farmacêuticas e de Alimentos, Faculdade de Bioquímica e Bioprospecção, Universidade Federal de Pelotas (UFPel), Pelotas, RS, Brasil.

\begin{abstract}
Natural additives in ruminant diet optimizes animal performance by controlling or modifying the rumen fermentation pattern. The aim of this study was to evaluate the effects of using Saccharomyces cerevisiae products during abrupt changes in dietary starch concentration on ruminal pH maintenance, performance and metabolism of confined sheep. Twenty adult ewes, crossbred Texel $x$ Corriedale $(44.7 \pm 6.97 \mathrm{Kg} \mathrm{BW})$ were divided into three groups: Control ( $n=6)$, Cultron X (yeast culture; $n=7$ ) and Cultron Pro (hydrolyzed yeast; $n=7)$, administered at a dose of $5 \mathrm{~g} /$ sheep/day $\left(10 \times 10^{10} \mathrm{CFU} / \mathrm{g}\right.$ DM). The experiment lasted 20 days divided into four periods, alternating between 40 and $60 \%$ concentrate. Blood and ruminal fluid were collected at the end of each period, and daily dry matter intake was measured to determine the average daily gain $(A D G)$. Blood tests included blood count and biochemical parameters such as glucose, urea, total plasma proteins (TPP), liver enzymes, acute phase proteins and minerals. There was an upward trend in ADG in group Cultron X compared to control in period 3. Although, ruminal $p H$ did not differ between groups, protozoan motility was higher in animals supplemented with hydrolyzed yeast. The Cultron Pro group showed an increase in TPP in periods 3 and 4, and AST in periods 2 and 3 compared to the control group. There was no difference in other metabolites. Yeast supplementation is a potential tool in times of feeding challenge, in which yeast culture is the most effective for improving performance of confined sheep being in improving performance of confined sheep.

Key words: yeast culture, hydrolyzed yeast, ruminal modulation, animal performance.
\end{abstract}

Utilização de produtos à base de Saccharomyces cerevisiae e seus efeitos sobre o ambiente ruminal e desempenho de ovinos submetidos a mudanças de dieta

RESUMO: A utilização de aditivos naturais na dieta de ruminantes é uma prática que otimiza o desempenho, controlando ou modificando o padrão de fermentação ruminal. O objetivo do estudo buscou avaliar os efeitos da utilização de produtos à base de Saccharomyces cerevisiae durante mudanças na concentração de amido da dieta sobre a manutenção do pH ruminal, desempenho e metabolismo de ovinos confinados.

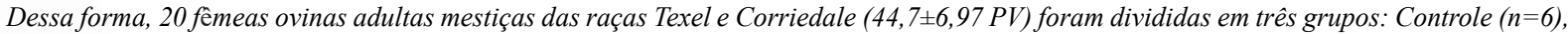
Cultron X (cultura de levedura; $n=7$ ) e Cultron Pro (levedura hidrolisada; $n=7)$, administrados na dose de $5 \mathrm{~g} /$ ovelha/dia $\left(10 x 10^{10}\right.$ ufc/g de MS). O experimento teve duração de 20 dias divididos em quatro periodos, alternando entre 40 e $60 \%$ de concentrado. Foram realizadas coletas de sangue e líquido ruminal ao final de cada período e mensuração da ingestão de matéria seca diariamente, a fim de determinar o ganho médio diário (GMD). As análises sanguíneas incluíram hemograma e parâmetros bioquímicos como glicose, ureia, proteínas plasmáticas totais (PPT), enzimas hepáticas, proteinas de fase aguda e minerais. Houve tendência de aumento no GMD no grupo Cultron X em relação ao controle no periodo 3. Apesar do $\mathrm{pH}$ ruminal não diferir entre grupos, a motilidade de protozoários foi melhor nos animais suplementados com levedura hidrolisada. O grupo Cultron Pro apresentou aumento de PPT nos periodos 3 e 4 e aumento nos níveis da enzima hepática AST nos periodos 2 e 3 em comparação ao grupo controle. Não houve diferença nos demais metabólitos. A suplementação com levedura apresentou-se como potencial ferramenta em momentos de desafio alimentar, sendo a cultura de levedura mais eficaz na melhora da performance de ovinos confinados. Palavras-chave: cultura de levedura, levedura hidrolisada, modulação ruminal, performance. 


\section{INTRODUCTION}

Intensification of animal production seeking to maximize the performance of ruminants is closely linked to the increase in the use of foods with high energy content in the diet for these animals (ALVES et al., 2003; YANG et al., 2012). However, the use of this tool can develop changes in the rumen environment, making the animal more susceptible to the development of metabolic disorders (RUSSEL \& RYCHLIK, 2001; MCCANN et al., 2016).

Due to the importance of the microbial population in the feeding efficiency of ruminants, the use of natural additives in the diet is a practice that optimizes the performance of animals, mainly those that act in the rumen, controlling or modifying the rumen fermentation pattern (WALLACE \& NEWBOLD, 1993; ENJALBERT et al., 1999). Among the additives used, supplementation with Saccharomyces cerevisiae strains has stood out in modulating the rumen environment and improving the health and performance of animals (ÖZTÜRK et al., 2015; CHAUCHEYRAS-DURAND et al., 2008).

There are different types of yeast for use in ruminant nutrition and, among them, hydrolyzed additives. They are composed of $\beta$-glucans and mannan oligosaccharides (MOS), main components of the cell wall of yeast cells (NOCEK et al., 2011), which act as immunomodulators (FRANKLIN et al., 2005). Glucans are stimulators of macrophages, increasing the response to pathogens (MORAN et al., 2004), while MOS act as high-affinity ligands for pathogenic bacteria that affect the gastrointestinal tract of ruminants, inhibiting local colonization (BOUDERGUE et al., 2009; OFEK et al., 1977). Active yeasts, in turn, are characterized by a high concentration of viable cells (above 10 billion CFU/g), while yeast culture consists of a fermentation product containing cell wall, live cells, among a series of compounds, such as vitamins and amino acids, which provide an ideal growth medium for yeasts (NOCEK et al., 2011).

To date, there are few studies investigating ruminal modulation strategies in times of abrupt changes in diet, as well as the use of supplementation in order to reduce potential negative impacts of these changes. In this sense, the hypothesis of this research was that animals supplemented with yeast present $\mathrm{pH}$ stabilization and consequent modulation of the rumen environment when diet was changed, with positive effects on performance and metabolism. Thus, the objective of the study was to evaluate the effects of using two products based on Saccharomyces cerevisiae in periods of sudden change in the amount of concentrate in the diet on the maintenance of ruminal $\mathrm{pH}$, performance and metabolism of confined sheep.

\section{MATERIAL AND METHODS}

\section{Animals and experimental groups}

Twenty non-lactating crossbred ewes, Texel x Corriedale, aged between 24 and 36 months, average weight of $44.7 \pm 6.97$, were confined throughout the experimental period and assigned to pens of two and three animals, three pens for each treatment. The animals were divided into three groups according to body weight: Control Group (no supplementation; $\mathrm{n}=6$ ), Cultron $\mathrm{X}^{\circledR}$ Group (Aleris, São Paulo, Brazil), supplemented with Saccharomyces cerevisiae fermentation products containing live yeast in its formulation $\left(2 \times 10^{10} \mathrm{CFU} / \mathrm{g} \mathrm{DM}\right)(\mathrm{n}=7)$ and Cultron Pro ${ }^{\circledR}$ Group (Aleris, São Paulo, Brazil), supplemented with a product based on enzymatically hydrolyzed yeast $(n=7)$. Ewes belonging to the treatment groups received $5 \mathrm{~g}$ of the products daily, supplied in the feeders before morning meal.

\section{Experimental design and diets}

The experimental period was a period of 20 days, characterized by changes in the proportion of diet components every 5 days, alternating the amount of forage and concentrate, without prior adaptation. The study was divided into four experimental periods without prior adaptation, namely: P1, referring to $60 \%$ forage; $\mathrm{P} 2$, referring to $60 \%$ concentrate; $\mathrm{P} 3$, referring to $60 \%$ forage and $\mathrm{P} 4$, referring to $60 \%$ concentrate. The supplemented animals were subjected to a previous adaptation for 20 days, with the appropriate dose of each product. The sheep had individual feeders; the total diet was homogenized manually and offered twice a day, in the morning at 8:30 am and in the afternoon at 4:30 pm, consisting of corn silage, wheat meal, with water ad libitum. The diet was calculated at a proportion of $3 \%$ body weight DM. The nutritional composition of the ingredients is listed in table 1.

\section{Blood samples and hematological and biochemical analyses}

Blood was collected every five days (days $5,10,15$ and 20) by puncturing the jugular vein into a vacutainer system, before the morning meal at the end of each experimental period, totaling five collections per animal. The blood was drawn into three separate tubes, one containing 10\% EDTA for complete blood count, one with sodium fluoride for serum glucose analysis, and a third with clot activator 
Table 1 - Nutritional composition of the total diet used during the experimental period.

\begin{tabular}{lcc}
\hline & ---1 & \\
& & \\
Nutritional composition & & \\
Organic matter & 40 & 93.7 \\
Crude protein & 93.8 & 12.5 \\
NDF & 10.4 & 45.8 \\
ADF & 47.4 & 17.3 \\
Mineral matter & 19.3 & 6.3 \\
TDN & 6.2 & 75.8 \\
Digestibility & 73.9 & 75.4 \\
\hline
\end{tabular}

${ }^{*}$ Diet consisting of corn silage and wheat meal.

used for biochemical analysis. After collection, the samples containing 10\% EDTA were properly homogenized and analyzed in a hematology analyzer (BC Vet 2800 Mindray), for erythrogram and leukogram, and used for blood smears for leukocyte differentiation.

Blood samples for biochemical analyses were centrifuged at 3,000 rpm for 15 minutes, and the serum aliquots were poured into Eppendorf tubes and frozen. Measurements were performed for glucose, urea and total plasma protein (TPP) to assess energyprotein metabolism; gammaglutamyltransferase (GGT) and aspartate aminotransferase (AST) enzymes to evaluate liver function; acute phase proteins albumin, fibrinogen and paraoxonase (PON1), in addition to the minerals calcium $(\mathrm{Ca})$, magnesium $(\mathrm{Mg})$, sodium $(\mathrm{Na})$ and potassium $(\mathrm{K})$. The analyses were performed using a LabmaxPlenno ${ }^{\circledR}$ automated analyzer (Labtest, Minas Gerais, Brazil) and the PON1 activity was quantified by the rate of phenol extinction at $270 \mathrm{~nm}$ in serum samples, as described by Pradiee et al. (2017).

\section{Ruminal fluid collection}

Before the experimental period, a pilot experiment was conducted, in which it was decided to collect ruminal fluid two hours after feeding, taking into account the population results obtained. Thus, the fluid was collected on the days referring to blood collections, two hours after feeding, through an orogastric tube. The collected liquid was filtered through 4 layers of gauze, avoiding contamination of the sample with saliva, as described by DEHORITY (1984). Upon collection, ruminal $\mathrm{pH}$ was immediately measured with a portable digital $\mathrm{pH}$ meter $\left(\right.$ Hanna $^{\circledR}$, Brazil), then the physical aspects of the fluid, such as color, odor and consistency, were evaluated. The color of the liquid was classified as olive green (1), pure green (2), yellowish brown (3), milky gray (4) and blackish green (5), while the grades for odor assessment were considered aromatic (1), acid (2), putrid (3), ammoniacal (4) and odorless (5). Liquid consistency was classified into different degrees of viscosity, including watery, slightly viscous and viscous (grades 1, 2 and 3, respectively). The organoleptic evaluations were adapted from DIRKSEN (1993). Afterwards, the analyses were performed, starting with the visualization of ruminal protozoa motility under an optical microscope according to DIRKSEN (1993). Bacterial activity was indicated by the methylene blue reduction test and the sedimentation and fluctuation analysis were performed according to the methodology described by ROSENBERGER (1993).

\section{Performance analysis}

All animals were weighed on the days referring to collections, every five days, on a digital scale (Tru-Test ${ }^{\circledR}$, Brazil), before the morning meal. Thus, it was possible to determine the average daily gain (ADG) of the animals in each of the experimental periods. The total diet and leftovers were weighed twice a day, in order to measure the dry matter intake (DMI) in each period.

\section{Chemical analysis}

Samples of Total Mixed Ration (TMR) and leftover in the troughs were collected. The samples were analyzed for dry matter (DM), crude protein (CP), neutral detergent fiber (NDF), acid detergent fiber (FDA) and ashes, according to SILVA \& QUEIROZ (2002). Parameters of dry matter digestibility (DMD) and total digestible nutrients (TDN) were determined according to the following 
equations: $\mathrm{DMD}=88.9-(0.7779 \mathrm{X} \% \mathrm{ADF})$ and $\mathrm{TDN}$ $=87.84-(0.7 \mathrm{X} \% \mathrm{ADF})$, respectively, described in TEIXEIRA \& TEIXEIRA (1998).

\section{Statistical analysis}

The experimental design was completely randomized, in which pens were the experimental units. Statistical analyses were run using the SAS statistical program (SAS Institute Inc., Cary, USA, 2016). The mean values were analyzed using the MIXED MODELS method, considering the group fixed effects (Control, Cultron Pro and Cultron X), the time of collection and their interactions, and the random effect of animal. Data were analyzed according to the following model:

$\mathrm{Y}_{\mathrm{ijk}}=\mu+\mathrm{T}_{\mathrm{i}}+\mathrm{P}_{\mathrm{j}}+\mathrm{S}_{\mathrm{k}}+\mathrm{TP}_{\mathrm{ij}}+\mathrm{e}_{\mathrm{ij} \mathrm{j} k}$ where $Y_{i j k}$ is the dependent variable, $\mu$ is the overall mean, $\mathrm{T}_{\mathrm{i}}$ is the fixed effect of treatment $(\mathrm{i}=$ Control, Cultron Pro and Cultron X), $\mathrm{P}$ is the fixed effect of period $(\mathrm{j}=1 ; 2 ; 3 ; 4), \mathrm{S}_{\mathrm{k}}$ is the random effect of animal ( $\mathrm{k}=1$ to 20$), \mathrm{TP}_{\mathrm{ij}}$ is the interaction between treatment and period, and $\mathrm{e}_{\mathrm{ijk}}$ is the experimental error. Means were compared by Tukey-Kramer test. Effects of treatments were significant when $P$-values $<0.05$ and trends were discussed when $0.05<P<0.10$. The results are presented as mean \pm standard error of the mean.

\section{RESULTS}

Ruminal $\mathrm{pH}$ values did not differ between groups and experimental periods, as illustrated in figure 1. All animals presented $\mathrm{pH}$ values between 6.0 and 7.0, considered a physiological value for the species (FEITOSA, 2008). It was possible to observe an increasing trend in ruminal $\mathrm{pH}$ values in period 4 in relation to period 3 (6.28 x 6.13, respectively) $(\mathrm{P}=0.06)$ in all experimental groups.

The ruminal fluid showed two distinct colors, olive green and brownish yellow. The difference was detected only in the Cultron X group in period 1, with $85.71 \%$ animals showing olive green fluid and $14.29 \%$, brownish yellow. The aromatic odor observed in all groups during the experiment indicated that the animals in the study had conditions compatible with normal physiological parameters (GONZÁLEZ et al., 2000). Regarding the consistency of the fluid, during the entire experimental period, $42.8 \%$ animals in the Cultron Pro group had ideal viscosity, compared to $39.3 \%$ in the Cultron X group, and $33.3 \%$ in the control group. In period 2, there was a high number of animals with ruminal liquid with watery consistency in the three treatments, with the animals in the control group showing $100 \%$ abnormal consistency, followed by $85 \%$ in the Cultron X group, and $71 \%$ in the Cultron Pro group.

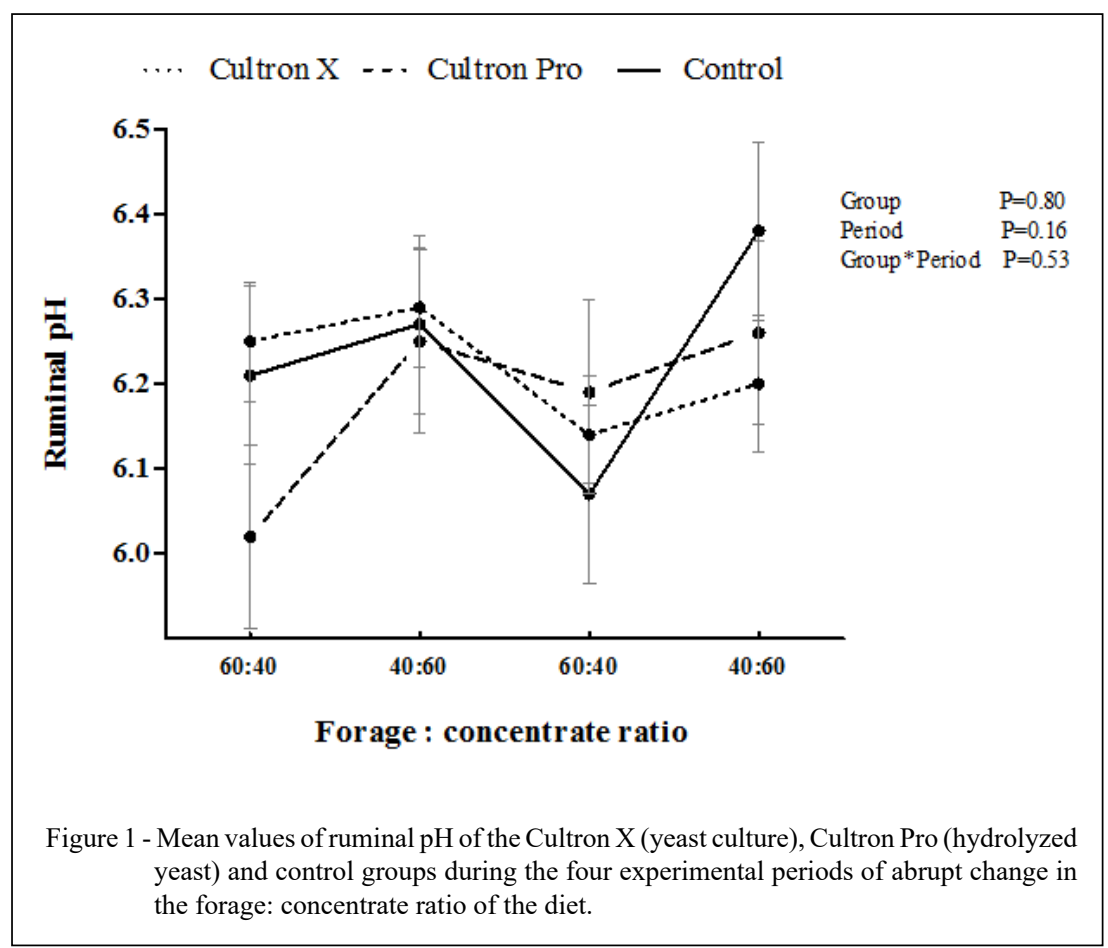

Ciência Rural, v.51, n.2, 2021. 
With respect to motility of ruminal protozoa, there was a significant difference between the groups $(\mathrm{P}<0.001)$. The animals in the control group had higher cases of reduced motility $(20.8 \%)$ compared to the Cultron X (3.57\%) and Cultron Pro $(0 \%)$ groups. The Cultron Pro group presented superior results $(\mathrm{P}<0.05)$ compared to the others, with $64.3 \%$ animals showed excellent motility of protozoa, compared to $39.3 \%$ and $20.8 \%$ in the Cultron X and control groups, respectively.

In the present study, there was no effect of supplementation on the fermentation activity of bacteria, all groups were within the normal range. Results of $\mathrm{pH}$, PRAM and TSF are listed in tables 2 and 3.

As for the zootechnical parameters analyzed, supplementation did not influence the DMI of the animals, with a significant difference only between the Cultron Pro and Cultron $\mathrm{X}$ groups $(\mathrm{P}=0.04)$.

Differences in ADG were detected between periods in all groups $(\mathrm{P}<0.001)$, especially in period 2 compared to the others. The group supplemented with
Cultron $\mathrm{X}$ showed a more intense reduction in this second period; however, there was a notable increase in this group in period 4 compared to period $2(-0.6 \mathrm{x}$ $0.4 \pm 0.09 \mathrm{~kg}$, respectively) $(\mathrm{P}=0.003)$, characterized by the same diet. In period 3, there was an upward trend in the Cultron $\mathrm{X}$ group compared to the control group $(\mathrm{P}=0.1)$. The means of DMI and $\mathrm{ADG}$ are presented in tables 2 and 3 .

In relation to the energy metabolism, there was a difference in serum glucose levels between the control and Cultron X groups $(53.7 \times 68.0 \pm 2.0 \mathrm{mg} /$ $\mathrm{dL})$ and between control and Cultron Pro (56.7 x 68.0 $\pm 2.0 \mathrm{mg} / \mathrm{dL}$ ) in period $1(\mathrm{P}=0.02)$ (Figure 2).

As for protein metabolism, there was a significant difference in the concentration of total plasma proteins between treatments, with a noticeable increase in the Cultron Pro group compared to the control group in period $3(6.64 \times 7.26 \pm 1.18 \mathrm{~g} /$ $\mathrm{dL} ; \mathrm{P}=0.02)$ and in period $4(7.07 \times 6.67 \pm 0.09 \mathrm{~g} /$ $\mathrm{dL} ; \mathrm{P}=0.01$ ), indicating increased concentrations in animals supplemented with hydrolyzed yeast.

Table 2 - Zootechnical indices, ruminal parameters and blood metabolite levels of animals in the Cultron X (yeast culture), Cultron Pro (hydrolyzed yeast) and Control groups in periods 1 and 2.

\begin{tabular}{|c|c|c|c|c|c|c|c|c|c|c|}
\hline & \multicolumn{4}{|c|}{-------------------------'Period 1---------------------- } & \multicolumn{4}{|c|}{ 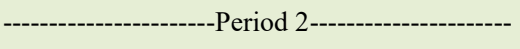 } & \multicolumn{2}{|c|}{---------P-value------- } \\
\hline & ----------. & ------60 & --------. & ------- & -------- & --------4( & ------- & -------- & & \\
\hline & C. $\mathrm{X}$ & C. Pro & CTL & SEM & C. X & C. Pro & CTL & SEM & Gru & Per \\
\hline $\mathrm{pH}$ & 6.2 & 6.0 & 6.2 & 6.2 & 6.2 & 6.2 & 6.1 & 6.1 & 0.80 & 0.16 \\
\hline PRAM & 3.5 & 2.2 & 2.8 & 1.5 & 1.7 & 2.3 & 3.0 & 2.8 & 0.29 & 0.003 \\
\hline TSF & 8.3 & 18.1 & 10.0 & 2.7 & 12.0 & 13.3 & 19.5 & 2.9 & 0.58 & 0.45 \\
\hline DMI & 2.7 & 2.6 & 2.6 & 0.08 & 2.2 & 2.2 & 2.2 & 0.08 & 0.11 & $<0.001$ \\
\hline $\mathrm{ADG}$ & 0.3 & 0.1 & 0.2 & 0.09 & -0.6 & -0.1 & -0.2 & 0.09 & 0.90 & $<0.001$ \\
\hline Alb & 2.9 & 3.0 & 3.0 & 0.04 & 2.8 & 2.9 & 3.0 & 0.04 & 0.52 & 0.23 \\
\hline PON & 256.5 & 260.4 & 238.8 & 14.3 & 258.9 & 273.0 & 273.7 & 14.3 & 0.9 & 0.66 \\
\hline Fibri & 600.0 & 571.4 & 566.6 & 61.8 & 514.2 & 542.8 & 666.6 & 61.8 & 0.47 & 0.1 \\
\hline AST & 83.1 & 95.2 & 83.3 & 2.6 & $89.0^{\mathrm{ab}}$ & $87.8^{\mathrm{a}}$ & $83.6^{\mathrm{b}}$ & 2.6 & $<0.01$ & 0.75 \\
\hline GGT & 52.2 & 50.2 & 52.3 & 2.0 & 49.4 & 55.1 & 55.3 & 2.0 & 0.15 & 0.8 \\
\hline Glu & $53.7^{\mathrm{a}}$ & $56.7^{\mathrm{a}}$ & $68.0^{\mathrm{b}}$ & 2.0 & $54.6^{\mathrm{a}}$ & $66.1^{\mathrm{b}}$ & $64.3^{\mathrm{ab}}$ & 2.0 & 0.02 & $<0.01$ \\
\hline Ur & 36.1 & 30.1 & 32.3 & 1.6 & 45.1 & 41.0 & 39.0 & 1.6 & 0.09 & $<0.01$ \\
\hline ТPP & 6.7 & 6.6 & 6.5 & 0.1 & 6.8 & 7.1 & 7.0 & 0.1 & 0.01 & 0.07 \\
\hline $\mathrm{Ca}$ & 8.7 & 8.6 & 8.4 & 0.1 & 8.0 & 8.6 & 8.3 & 0.1 & 0.08 & $<0.01$ \\
\hline $\mathrm{Na}$ & $143.4^{\mathrm{a}}$ & $143.8^{\mathrm{a}}$ & $135.8^{\mathrm{a}}$ & 1.7 & $141^{\mathrm{a}}$ & $144.2^{\mathrm{a}}$ & $139.6^{\mathrm{a}}$ & 1.7 & 0.44 & $<0.01$ \\
\hline $\mathrm{K}$ & $3.8^{\mathrm{a}}$ & $4.1^{\mathrm{ab}}$ & $4.4^{\mathrm{b}}$ & 0.09 & $3.69^{\mathrm{a}}$ & $4.0^{\mathrm{a}}$ & $3.7^{\mathrm{a}}$ & 0.09 & 0.02 & 0.07 \\
\hline $\mathrm{Mg}$ & $3.3^{\mathrm{a}}$ & $3.3^{\mathrm{a}}$ & $3.4^{\mathrm{a}}$ & 0.1 & $4.22^{\mathrm{a}}$ & $4.0^{\mathrm{a}}$ & $3.9^{\mathrm{a}}$ & 0.1 & 0.55 & $<0.01$ \\
\hline
\end{tabular}

60:40=Diet $60 \%$ forage and 40\%concentrate; 40:60=Diet 40\% forage and 60\% concentrate; C. X=Cultron X Group (yeast culture-based product); C. Pro = Cultron Pro Group (hydrolyzed yeast-based product); CTL = Control Group; SEM = Standard error of the mean; Gru = Group; Per = Period; PRAM = methylene blue reduction test; TSF = Sedimentation and fluctuation test; DMI = Dry matter intake; $\mathrm{ADG}=$ Average daily gain; Alb = albumin; $\mathrm{PON}=$ Paraoxonase; Fibri $=$ Fibrinogen; Glu $=\mathrm{Glucose}$; Ur $=\mathrm{Urea} ; \mathrm{TPP}=$ total plasma protein; $\mathrm{Ca}=$ Calcium; $\mathrm{Na}=$ Sodium; $\mathrm{K}=$ Potassium; $\mathrm{Mg}=$ Magnesium. DMI and ADG evaluated in $\mathrm{Kg} /$ day; Alb and TPP analyzed in $\mathrm{g} / \mathrm{dL}$; Fibri, Glu, Ur, Ca and $\mathrm{Mg}$ analyzed in $\mathrm{mg} / \mathrm{dL}$; AST and GGT analyzed in U/L; PON analyzed in U/mL; Na and K analyzed in $\mathrm{mmol} / \mathrm{L}$. 
Table 3 - Zootechnical indices, ruminal parameters and blood metabolite levels of animals in the Cultron X (yeast culture), Cultron Pro (hydrolyzed yeast) and Control groups in periods 3 and 4 .

\begin{tabular}{|c|c|c|c|c|c|c|c|c|c|c|}
\hline & \multicolumn{4}{|c|}{-------------------------Period3----------------------- } & \multicolumn{4}{|c|}{ 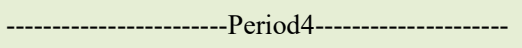 } & \multicolumn{2}{|c|}{---------- $P$-value------- } \\
\hline & \multicolumn{4}{|c|}{--------------------------60:40------------------------- } & \multicolumn{4}{|c|}{--------------------------40:60-------------------------- } & & \\
\hline & C. X & C. Pro & CTL & E.P. & C. X & C. Pro & CTL & SEM & Gru & Per \\
\hline $\mathrm{pH}$ & 6.1 & 6.1 & 6.0 & 0.05 & 6.2 & 6.2 & 6.3 & 0.05 & 0.80 & 0.16 \\
\hline PRAM & 3.0 & 2.8 & 2.3 & 0.2 & 3.5 & 3.2 & 2.6 & 0.2 & 0.29 & 0.003 \\
\hline TSF & 20.0 & 18.3 & 17.6 & 2.8 & 14.4 & 19.5 & 10.2 & 3.03 & 0.58 & 0.45 \\
\hline DMI & 2.7 & 2.5 & 2.6 & 2.6 & 2.1 & 1.8 & 2.1 & 2.0 & 0.11 & $<0.001$ \\
\hline $\mathrm{ADG}$ & 0.4 & 0.2 & 0.1 & 0.09 & 0.4 & 0.2 & 0.3 & 0.09 & 0.90 & $<0.001$ \\
\hline Alb & $3.0^{\mathrm{ab}}$ & $3.1^{\mathrm{a}}$ & $2.8^{\mathrm{b}}$ & 0.04 & 3.0 & 3.0 & 3.1 & 0.05 & 0.52 & 0.23 \\
\hline PON & 235.0 & 250.6 & 245.0 & 14.3 & 258.1 & 254.6 & 255.7 & 14.7 & 0.9 & 0.66 \\
\hline Fibri & 728.5 & 800.0 & 766.6 & 61.8 & 485.7 & 771.4 & 566.6 & 61.8 & 0.47 & 0.1 \\
\hline AST & $81.1^{\mathrm{a}}$ & $97.7^{b}$ & $80.1^{\mathrm{a}}$ & 2.6 & $83.2^{\mathrm{a}}$ & 9.4 & 90.8 & 2.8 & $<0.01$ & 0.75 \\
\hline GGT & 47.8 & 49.7 & 57.1 & 2.0 & 49.5 & 57.6 & 54.5 & 2.1 & 0.15 & 0.8 \\
\hline Glu & 50.7 & 50.8 & 53.3 & 2.0 & 57.7 & 60.8 & 56.8 & 2.0 & 0.02 & $<0.01$ \\
\hline $\mathrm{Ur}$ & 32.4 & 30.2 & 27.3 & 1.6 & 31.8 & 36.4 & 30.0 & 1.7 & 0.09 & $<0.01$ \\
\hline TPP & $6.9^{\mathrm{ab}}$ & $7.2^{\mathrm{a}}$ & $6.6^{\mathrm{b}}$ & 0.1 & $6.5^{\mathrm{a}}$ & $7.1^{\mathrm{b}}$ & $6.5^{\mathrm{a}}$ & 0.1 & 0.01 & 0.07 \\
\hline $\mathrm{Ca}$ & 8.5 & 8.9 & 8.4 & 0.1 & 7.6 & 7.9 & 7.4 & 0.1 & 0.08 & $<0.01$ \\
\hline $\mathrm{Na}$ & 136.5 & 142.7 & 143.5 & 1.7 & 133.1 & 133.2 & 134.5 & 1.8 & 0.44 & $<0.01$ \\
\hline $\mathrm{K}$ & 3.9 & 4.1 & 4.1 & 0.09 & 3.8 & 4.2 & 3.8 & 0.1 & 0.02 & 0.07 \\
\hline \multirow[t]{4}{*}{$\mathrm{Mg}$} & 4.2 & 4.0 & 3.9 & 0.1 & 4.1 & 3.9 & 4.1 & 0.1 & 0.55 & $<0.01$ \\
\hline & \multicolumn{4}{|c|}{ 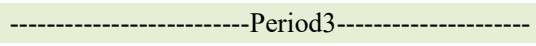 } & \multicolumn{4}{|c|}{ 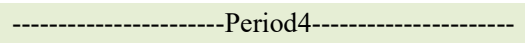 } & \multicolumn{2}{|c|}{-----------P-value-------- } \\
\hline & \multicolumn{4}{|c|}{---------------------------60:40----------------------- } & \multicolumn{4}{|c|}{---------------------------40:60---------------------- } & & \\
\hline & C. X & C. Pro & CTL & E.P. & C. X & C. Pro & CTL & SEM & Gru & Per \\
\hline $\mathrm{pH}$ & 6.1 & 6.1 & 6.0 & 0.05 & 6.2 & 6.2 & 6.3 & 0.05 & 0.80 & 0.16 \\
\hline PRAM & 3.0 & 2.8 & 2.3 & 0.2 & 3.5 & 3.2 & 2.6 & 0.2 & 0.29 & 0.003 \\
\hline TSF & 20.0 & 18.3 & 17.6 & 2.8 & 14.4 & 19.5 & 10.2 & 3.03 & 0.58 & 0.45 \\
\hline DMI & 2.7 & 2.5 & 2.6 & 2.6 & 2.1 & 1.8 & 2.1 & 2.0 & 0.11 & $<0.001$ \\
\hline $\mathrm{ADG}$ & 0.4 & 0.2 & 0.1 & 0.09 & 0.4 & 0.2 & 0.3 & 0.09 & 0.90 & $<0.001$ \\
\hline Alb & $3.0^{\mathrm{ab}}$ & $3.1^{\mathrm{a}}$ & $2.8^{b}$ & 0.04 & 3.0 & 3.0 & 3.1 & 0.05 & 0.52 & 0.23 \\
\hline PON & 235.0 & 250.6 & 245.0 & 14.3 & 258.1 & 254.6 & 255.7 & 14.7 & 0.9 & 0.66 \\
\hline Fibri & 728.5 & 800.0 & 766.6 & 61.8 & 485.7 & 771.4 & 566.6 & 61.8 & 0.47 & 0.1 \\
\hline AST & $81.1^{\mathrm{a}}$ & $97.7^{\mathrm{b}}$ & $80.1^{\mathrm{a}}$ & 2.6 & $83.2^{\mathrm{a}}$ & 9.4 & 90.8 & 2.8 & $<0.01$ & 0.75 \\
\hline GGT & 47.8 & 49.7 & 57.1 & 2.0 & 49.5 & 57.6 & 54.5 & 2.1 & 0.15 & 0.8 \\
\hline Glu & 50.7 & 50.8 & 53.3 & 2.0 & 57.7 & 60.8 & 56.8 & 2.0 & 0.02 & $<0.01$ \\
\hline $\mathrm{Ur}$ & 32.4 & 30.2 & 27.3 & 1.6 & 31.8 & 36.4 & 30.0 & 1.7 & 0.09 & $<0.01$ \\
\hline TPP & $6.9^{\mathrm{ab}}$ & $7.2^{\mathrm{a}}$ & $6.6^{\mathrm{b}}$ & 0.1 & $6.5^{\mathrm{a}}$ & $7.1^{\mathrm{b}}$ & $6.5^{\mathrm{a}}$ & 0.1 & 0.01 & 0.07 \\
\hline $\mathrm{Ca}$ & 8.5 & 8.9 & 8.4 & 0.1 & 7.6 & 7.9 & 7.4 & 0.1 & 0.08 & $<0.01$ \\
\hline $\mathrm{Na}$ & 136.5 & 142.7 & 143.5 & 1.7 & 133.1 & 133.2 & 134.5 & 1.8 & 0.44 & $<0.01$ \\
\hline K & 3.9 & 4.1 & 4.1 & 0.09 & 3.8 & 4.2 & 3.8 & 0.1 & 0.02 & 0.07 \\
\hline $\mathrm{Mg}$ & 4.2 & 4.0 & 3.9 & 0.1 & 4.1 & 3.9 & 4.1 & 0.1 & 0.55 & $<0.01$ \\
\hline
\end{tabular}

60:40= Diet $60 \%$ forage and 40\% concentrate; $40: 60=$ Diet $40 \%$ forage and $60 \%$ concentrate; C. X= Cultron X Group (yeast culturebased product); C. Pro = Cultron Pro Group (hydrolyzed yeast-based product); CTL = Control Group; SEM = Standard error of the mean; Gru = Group; Per = Period; PRAM = methylene blue reduction test; TSF $=$ Sedimentation and fluctuation test; DMI $=$ Dry matter intake; $\mathrm{ADG}=$ Average daily gain; $\mathrm{Alb}=$ albumin; $\mathrm{PON}=$ Paraoxonase; Fibri $=$ Fibrinogen; $\mathrm{Glu}=\mathrm{Glucose}$; Ur $=\mathrm{Urea} ; \mathrm{TPP}=$ total plasma protein; $\mathrm{Ca}=$ Calcium; $\mathrm{Na}=$ Sodium; $\mathrm{K}=$ Potassium; $\mathrm{Mg}=$ Magnesium. DMI and $\mathrm{ADG}$ evaluated in $\mathrm{Kg} / \mathrm{day} ; \mathrm{Alb}$ and $\mathrm{TPP}$ analyzed in g/dL; Fibri, Glu, Ur, Ca and Mg analyzed in mg/dL; AST and GGT analyzed in U/L; PON analyzed in U/mL; Na and K analyzed in $\mathrm{mmol} / \mathrm{L}$.

Total plasma proteins (TPP) are produced in the liver and their synthesis is related to the protein content of the diet and the nutritional status of the animal (GONZÁLEZ \& SCHEFFER, 2003).
In this study, TPP concentrations were higher in the Cultron Pro group and this increase may be related to the increase in protein content in the diet, since this product contains hydrolyzed yeast, 


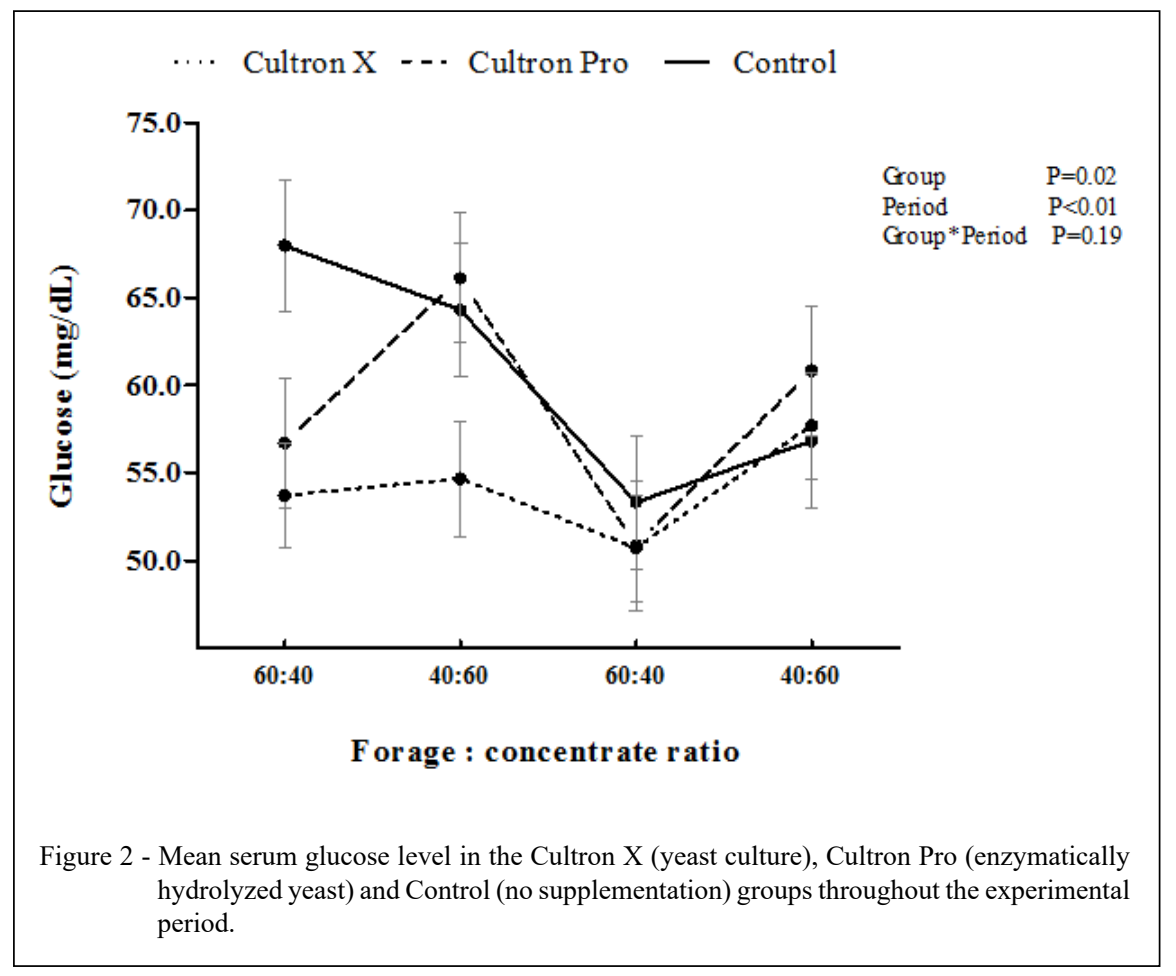

which provides a widely available protein source, in addition to favoring stimulatory factors for rumen microorganisms, increasing their concentration in the rumen environment and thus increasing microbial protein (MAO et al., 2013).

In addition, these proteins play a key role in immunity, as indicators of infectious processes (GONZÁLEZ et al., 2000). Hydrolyzed yeast, conversely, contains $\beta$-glucans and mannan oligosaccharides (MOS) in the cell wall, which basically act in the increase of function phagocytic cells, mainly macrophages, and can stimulate the response to antigens (CZECH et al., 2018), showing that the results of TPP associated with yeast components are configured as having great potential to increase quality and quantity of the immune response.

There was a difference in serum urea levels between experimental periods $(\mathrm{P}<0.001)$, with a significant increase in the first challenge with a higher proportion of concentrate in the diet. A difference was detected between the Cultron $\mathrm{X}$ group and the control group $(\mathrm{P}=0.03)$, with higher values in the supplemented group (36.39 $\mathrm{x}$ $32.16 \pm 1.94 \mathrm{mg} / \mathrm{dL}$ ).

The Cultron Pro group showed higher levels of the AST enzyme compared to the control group in periods 2 and $3(\mathrm{P}=0.002)$, but the levels of the GGT enzyme were not altered by supplementation $(\mathrm{P}>0.05)$. The other metabolic markers showed no significant difference between experimental groups, as listed in tables 2 and 3 .

\section{DISCUSSION}

The rumen $\mathrm{pH}$ is one of the variables that directly interfere with the microbial population and the activity of protozoa (DAYANI et al., 2007). The $\mathrm{pH}$ of ruminal fluid can vary between 5.5 and 6.2 in diets with a higher level of concentrate, while in diets with a greater participation of forage the values are between 6.2 and 7.0 (ODENYO et al., 1997). In this case, the $\mathrm{pH}$ fluctuations were observed in small proportions, keeping within the physiological values for the species, which points out the maintenance of the rumen environment and a balance of microbial activity.

According to FEITOSA (2008), the fluid consistency should be slightly viscous, indicating the presence of supernatant particles of nutrients and microorganisms in an adequate amount.

The high number of animals with ruminal fluid of abnormal consistency in the control group may be related to microbial inactivity, demonstrating that animals supplemented with yeast culture or hydrolyzed yeast may have less negative consequences 
in the rumen environment when challenged with diets with higher starch content.

Protozoa play an important role in controlling the ruminal fluid $\mathrm{pH}$, being able to easily engulf starch granules. These microorganisms are responsible for up to $45 \%$ amylolytic activity in the rumen, significantly increasing their population in animals supplemented with high-concentrate diets (BORGES et al., 2002). In the present study, a greater number of cases with active protozoan motility were identified in the first challenge period with a more concentrated diet, corroborating HUHTANEN (1992), who reported a greater number of protozoa when there was a replacement of fiber with grain in the diet. This result is because these microorganisms digest starch more slowly than bacteria, indirectly helping to control $\mathrm{pH}$ and leading to a decrease in the number of amylolytic bacteria through competition for the substrate, also participating in the fermentation of lactate present in the rumen.

When comparing the supplemented groups to the control group, it is possible to observe that both supplemented groups had a greater number of animals with good to excellent protozoan motility, which demonstrates the effectiveness of supplementation in modulating the fermentation, directly reflecting on the activity of ruminal protozoa.

The methylene blue reduction test (PRAM) reflects the anaerobic fermentative metabolism of the microbial population (FEITOSA, 2008). This author stated that the reduction time of up to 3 minutes is the result of an active microbiota, which can be reduced in a highly concentrated diet, which did not occur in the present study, since, regardless of the energy content of the diet, all groups remained within the physiological values.

The methylene blue reduction test (PRAM) reflected the anaerobic fermentative metabolism of the microbial population (FEITOSA, 2008). This author stated that the reduction time of up to 3 minutes is the result of an active microbiota, which can be reduced with a high-concentrate diet, which did not occur in the present study, since, regardless of the diet energy content, all groups remained within the physiological values.

Although, supplementation did not influence DMI, animals supplemented with yeast culture showed better feeding efficiency compared to the control group, in period 3. This corroborated DING et al. (2008), in which sheep supplemented with live yeast at a dose of $10 \times 10^{9} \mathrm{CFU} /$ day showed $7.3 \%$ improvement in feed efficiency compared to the control group, but without influence on DMI. In contrast, STELLA et al. (2007), evaluating a diet with $47 \%$ concentrate DM, and ABD EL-GHANI (2004), with $60 \%$ concentrate DM, observed an increase in the DMI of these animals, resulting in an increase in milk production in goats.

DING et al. (2008) evaluated the digestibility of hemicellulose, which increased from $55.7 \%$ to $62.4 \%$ in diets supplemented with live yeast, which, according to SALINAS-CHAVIRA et al. (2017), would have a beneficial effect on the regulation of DMI as a result of greater fiber degradation, and microbial protein synthesis in the rumen. In a study by DIAS et al. (2018), DMI values were similar between the non-supplemented group receiving a low starch diet and the group supplemented with yeast fed a more energetic diet, which makes it possible to verify that yeast has a beneficial effect on the rumen environment, minimizing the effects from the concentrates supply.

Another study conducted by DIAS et al. (2018) supports this statement, demonstrating that supplementation increased fiber digestibility in dairy cows fed a high starch diet, which could positively influence DMI rates. This is not consistent with the results obtained in the present study, in which a reduction in DMI was reported in periods with a higher proportion of concentrate in the diet, corroborating DESNOYERS et al. (2009), who stated that supplementation with $S$. cerevisiae increases the digestibility of organic matter with beneficial results in more fibrous diets compared to energy diets.

The difference in ADG values of the Cultron $\mathrm{X}$ group in periods 2 and 4 can be explained by the better adaptation at the rumen level of animals supplemented with yeast culture, since the abrupt change in feeding without prior adaptation does not guarantee an appropriate digestion and ruminal fermentation (FARENZENA et al., 2016), indicating that these individuals go through feeding challenge periods less severely.

According to WALLACE \& NEWBOLD (1992), the effects of yeast in the rumen trigger a modulation in the microbial population, contributing to improve feeding efficiency in dairy cows, which is supported by ZHU et al. (2017), who identified a significant increase in the number of cellulolytic bacteria and a reduction in lactateproducing species in response to supplementation. HADDAD \& GOUSSOUS (2005) stated that supplementation with yeast culture has a positive effect on nutrient digestibility, resulting in greater ADG and higher feeding efficiency in sheep fed a diet with $80 \%$ concentrate. 
The increase in serum glucose levels was expected due to the greater energy supply, as reported by DIAS et al. (2018). According to the authors, diets with high-concentrate stimulated the concentrations of propionate in the rumen, which favors gluconeogenesis and increases glucose levels.

According to KHALID et al. (2011), the lower concentration of plasma glucose in animals receiving supplementation can be ascribed to greater fiber digestion as a consequence of the modulation in the rumen environment provided by the action of yeast. This statement can be seen in the study by YUAN et al. (2015), who identified that supplementation with two different doses of yeast tended to reduce blood glucose levels in cows. Contrary to the results obtained, ABO EL-NOR \& KHOLIF (1998) reported a higher level of glucose in supplemented cows. However, HRISTOV et al. (2010) and OLAGARAY et al. (2019) reported no effect of supplementation on plasma glucose levels in dairy cows. It is worth mentioning that the control group has already started the experimental period with high levels of glucose, thereby maintaining during periods with low energy intake. This demonstrated that, probably, supplemented animals may have an improved starch metabolization efficiency in cases of greater energy supply, since at that time, the glucose levels between groups were similar, even with the control group starting from higher glycemic index.

Total plasma proteins (TPP) are produced in the liver and their synthesis is related to the protein content of the diet and the nutritional status of the animal (GONZÁLEZ \& SCHEFFER, 2003). In this study, TPP levels were higher in the Cultron Pro group and this increase may be related to the increase in protein content in the diet, since this product contains hydrolyzed yeast, which provides a highly available protein source, in addition to favoring stimulatory factors for rumen microorganisms, increasing their concentration in the rumen and thus increasing microbial protein (MAO et al., 2013).

Further, these proteins play an important role in immunity, as indicators of infectious processes (GONZÁLEZ et al., 2000). In turn, hydrolyzed yeast contains $\beta$-glucans and mannan oligosaccharides (MOS) in the cell wall, which basically act in the increase of phagocytic cells, mainly macrophages, and can stimulate the response to antigens $(\mathrm{CZECH}$ et al., 2018), showing that the TPP results associated with yeast components are configured as having great potential to increase the quality and quantity of the immune response.

Urea is a metabolite produced by the liver by recycling rumen ammonia from the fermentation of nitrogen ingested in the diet, and part of it is metabolized in the liver and can be excreted via urine or return to the rumen via saliva or bloodstream (BERCHIELLI et al., 2011). In the present study, the concentrations of this metabolite in the first challenge were higher than the reference values set by GONZÁLEZ et al. (2000). This may suggest that the high levels may be related to the protein content of the diet, since there was an increase in the percentage of crude protein when switching the diet based on forage to a higher proportion of concentrate.

An increase in the level of AST enzyme was observed after the period with the highest energy supply, which remained until the end of the following period. The increase of this metabolite in animals fed a diet rich in energy was also reported by SCHWEGLER et al. (2014), demonstrating that there was some liver overload in both periods. In addition, the authors observed that the increase in AST levels was maintained even after a period of recovery from induction of acidosis.

TABELEÃO et al. (2008) identified that the inclusion of yeast-based additives in a balanced diet promotes changes in liver function, which were evidenced by the increased activity of GGT enzyme during the adaptation period, which did not occur in the present study, but demonstrates that these products may be related to the increase in the activity of hepatocytes. NASROLLAHI et al. (2019) and XU et al. (2016) reported an increase in the serum activity of AST in cows with lower ruminal $\mathrm{pH}$, indicating that there is a relationship between the drop in $\mathrm{pH}$ and the liver efficiency of these animals, partially explaining the results reported in the present study. Still, NASROLLAHI et al. (2019) suggested that AST serum activity may be a possible indicator of susceptibility to low ruminal $\mathrm{pH}$ values.

Additives containing viable cells tend to modulate the rumen environment in a more direct way (CHAUCHEYRAS-DURAND et al., 2008), which is closely related to health; and consequently, to liver function. Thus, the use of hydrolyzed yeasts (absence of viable cells) may not act directly on rumen maintenance, reflecting changes in liver metabolism due to changes in the rumen fermentation pattern, especially during feeding challenge, corroborating the results reported at both liver and rumen levels in the present study.

\section{CONCLUSION}

Saccharomyces cerevisiae yeast-based products are a potential tool in times of dietary changes,

Ciência Rural, v.51, n.2, 2021. 
with direct positive effects on animal performance and metabolism, with yeast culture showing greater effects on the performance of confined sheep.

\section{ACKNOWLEDGEMENTS}

The authors are grateful to the Aleris Nutrition ${ }^{\circledR}$ company for providing the products and financial support for this research; Universidade Federal de Pelotas (UFPel), Núcleo de Pesquisa, Ensino e Extensão em Pecuária (NUPEEC) and Coordenação de Aperfeiçoamento de Pessoal de Nível Superior (CAPES), Brazil, for financing a part of this project.

\section{BIOETHICS AND BIOSSECURITY COMMITTEE APPROVAL}

All procedures involving animals in this study were in accordance with the established by the Animal Ethics and Experimentation Committee of the Federal University of Pelotas, registered and approved under number 4100 .

\section{DECLARATION OF CONFLICT OF INTERESTS}

The authors declare no conflict of interest. The founding sponsors had no role in the design of the study; in the collection, analyses, or interpretation of data; in the writing of the manuscript, and in the decision to publish the results.

\section{AUTHORS' CONTRIBUTIONS}

LT carried out experiments with animals and laboratory analysis, analyzed the data, and wrote the scientific article. $\mathrm{AB}$ assisted in the statistical analysis of the experimental data, writing and revision of the manuscript. $\mathrm{CB}$ coordinated and supervised all stages of the experiment, as well as revised and assisted in the writing of the manuscript. MC guided all stages of the project. MC, ES, VR and FD enabled all stages of the experiment and provide the necessary infrastructure to carry out the project. All authors agree with the final version of this manuscript.

\section{REFERENCES}

ABD EL-GHANI, A. A. Influence of diet supplementation with yeast culture (Saccharomyces cerevisiae) on performance of Zaraibi goats. Small ruminant research, v.52, n.3, p.223-229, 2004. Available from: <https://www.sciencedirect.com/science/ article/pii/S0921448803002815>. Accessed: Oct. 23, 2019. doi: 10.1016/j.smallrumres.2003.06.002.

ABO EL-NOR, S. A. H.; KHOLIF, A. M. Effect of supplementation of live yeast culture in the diet on the productive performance of lactating buffaloes. Milchwissenschaft, v.53, n.12, p.663666, 1998. Available from: <https://www.researchgate.net/ publication/259863735_Effect_of_supplementation_of_live yeast culture in the diet_on_the productive_performance_of lactating_buffaloes>. Accessed: Oct. 23, 2019.

ALVES, K. S. et al. Dietary energy levels for Santa Inês sheep: apparent digestibility. Revista Brasileira de Zootecnia, v.32, n.6, p.1962-1968, 2003. Available from:
<http://www.scielo.br/pdf/\%0D/rbz/v32n6s2/20966.pdf $>$. Accessed: Oct. 23, 2019.

BERCHIELLI, et al. Nutrição de ruminantes. 2 ed. Jaboticabal: FUNEP, 2011.

BORGES, N. C. et al. Avaliação do suco ruminal de bovinos "a fresco" e após 12 horas. Ciência Animal Brasileira, v.3, n.2, p.5763, 2002. Available from: <https://repositorio.bc.ufg.br/xmlui/ handle/ri/12359>. Accessed: Oct. 29, 2019.

BOUDERGUE, C. et al. Review of mycotoxin-detoxifying agents used as feed additives: mode of action, efficacy and feed/food safety. EFSA Supporting Publication, v.6, n.9, 192p., 2009. Available from: $<$ http://efsa.onlinelibrary.wiley.com/doi/abs/10.2903/sp.efsa.2009. EN-22>. Accessed: Oct. 29, 2019. doi: 10.2903/sp.efsa.2009.EN-22.

CHAUCHEYRAS-DURAND, F. et al. Effects of active dry yeasts on the rumen microbial ecosystem: past, present and future. Anim. Feed Sci. Technol., v.145, p.5-26, 2008. Available from: $<$ https://www.sciencedirect. com/science/article/pii/S0377840107002787?via\%3Dihub>. Accessed: Oct. 29, 2019. doi: 10.1016/j.anifeedsci.2007.04.019.

CZECH, A. et al. Effect of dietary supplementation with Yarrowialipolytica or Saccharomyces cerevisiae yeast and probiotic additives on haematological parameters and the gut microbiota in piglets. Res. Vet. Sci., v.119, p.221-227, 2018. Available from: $<$ https://www. sciencedirect.com/science/article/abs/pii/S0034528817306689>. Accessed: Oct. 28, 2019. doi: 10.1016/j.rvsc.2018.06.007.

DAYANI, O. et al. Effects of dietary whole cottonseed and crude protein level on rumen protozoal population and fermentation parameters. Small Ruminant Research, v.69, n.1-3, p.36-45, 2007. Available from: <https://www.sciencedirect.com/science/ article/abs/pii/S0921448805005043>. Accessed: Oct. 28, 2019. doi: 10.1016/j.smallrumres.2005.12.007.

DEHORITY, B. A. Evaluation of subsampling and fixation procedures used for counting rumen protozoa. Applied and Environmental Microbiology, v.48, n.1, p.182-185, 1984. Available from: <https://www.ncbi.nlm.nih.gov/pmc/articles/ PMC240360>. Accessed: Oct. 28, 2019.

DESNOYERS M. et al., Meta-analysis of the influence of Saccharomyces cerevisiae supplementation on ruminal parameters and milk production of ruminants. American Dairy Science Association, v.92, n.4, p.1620-1632, 2009. Available from: <https:// www.sciencedirect.com/science/article/pii/S0022030209704746>. Accessed: Oct. 20, 2019. doi: 10.3168/jds.2008-1414.

DIAS, A. L. G. et al. Effects of supplementing yeast culture to diets differing in starch content on performance and feeding behavior of dairy cows. Journal of Dairy Science, v.101, n.1, p.186-200, 2018. Accessed: Oct. 20, 2019.

DING, J. et al. Effect of monensin and live yeast supplementation on growth performance, nutrient digestibility, carcass characteristics and ruminal fermentation parameters in lambs fed steam-flaked corn-based diets. Asian-Australasian Journal of Animal Sciences, v.21, n.4, p.547-554, 2008. Available from: <https:// www.ajas.info/journal/view.php?number $=21814>$. Accessed: Oct. 20, 2019. doi: 10.5713/ajas.2008.70353.

DIRKSEN G., et al. Sistema digestivo. In: ROSEMBERGER, G. Exame Clínico dos Bovinos. 3.ed. Rio de Janeiro: Guanabara Koogan, 1993, p.166-228. 
ENJALBERT, F. et al. Effects of yeast culture (Saccharomyces cerevisiae) on ruminal digestion in non-lactating dairy cows. Anim. Feed, v.76, n.3-4, p.195-206, 1999. Available from: <https://www. sciencedirect.com/science/article/pii/S0377840198002302>. Accessed: Oct. 23, 2019. doi: 10.1016/S0377-8401(98)00230-2.

FARENZENA, R. et al. Minimum length of the adaptation and collection period in digestibility trials with sheep fed ad libitum only forage or forage plus concentrate. Journal of Animal Physiology and Animal Nutrition. 2016. Available from: $<$ https:// onlinelibrary.wiley.com/doi/full/10.1111/jpn.12550>. Accessed: Oct. 23, 2019. doi: 10.1111/jpn.12550.

FEITOSA, F.L.F. Semiologia Veterinária: A arte do diagnóstico. São Paulo: Roca, 2004.

FRANKLIN, S. T. et al. Immune parameters of dry cows 404 fed mannan oligosaccharide and subsequent transfer of immunity to calves, Journal of Dairy Science, v.88, n.2, p.766-775, 2005. Available from: <https://www.sciencedirect.com/science/article/ pii/S0022030205727405>. Accessed: Oct. 25, 2019. doi: 10.3168/ jds.S0022-0302(05)72740-5.

GONZÁLEZ, F.H.D. et al. Uso de provas de campo e de laboratório clínico em doenças metabólicas e ruminais dos bovinos. Porto Alegre: Gráfica da Universidade Federal do Rio Grande do Sul, 2000. Available from: <https://www.lume.ufrgs. br/bitstream/handle/10183/26658/000283211.pdf?se>. Accessed: Oct. 25,2019 .

GONZÁLEZ, F. H. D; SCHEFFER, J. F. S. Perfil sanguíneo: ferramenta de análise clínica, metabólica e nutricional. In: I SIMPÓSIO DE PATOLOGIA CLÍNICA VETERINÁRIA DA REGIÃO SUL DO BRASIL, 1., 2003, Porto Alegre, RS. Anais do I Simpósio de Patologia Clínica Veterinária da Região Sul do Brasil. Porto Alegre: Gráfica da Universidade Federal do Rio Grande do Sul, 2003, 98p., p.73-88. Available from: $<$ https://www. lume.ufrgs.br/bitstream/handle/10183/13177/000386508.pdf>. Accessed: Oct. 25, 2019.

HADDAD, S. G.; GOUSSOUS, S. N. Effect of yeast culture supplementation on nutrient intake, digestibility and growth performance of Awassi lambs. Animal Feed Science and Technology, v.118, n.3-4, p.343-348,2005. Available from: $<$ https:// www.sciencedirect.com/science/article/pii/S0377840104002317>. Accessed: Oct. 24, 2019. doi: 10.1016/j.anifeedsci.2004.10.003.

HRISTOV, A. N. et al. Effect of Saccharomyces cerevisiae fermentation product on ruminal fermentation and nutrient utilization in dairy cows. Journal of Dairy Science, v.93, n.2, p.682-692, 2010. Available from: <https://www.sciencedirect. com/science/article/pii/S0022030210715101>. Accessed: Oct. 24, 2019. doi: $10.3168 /$ jds.2009-2379.

KHALID, M. F. et al. Probiotics and lamb performance: A review. African Journal of Agricultural Research, v.6, n.23, p.51985203, 2011. Available from: <http://www.academicjournals.org/ app/webroot/article/article1380900106_Khalid\%20et\%20al.pdf $>$. Accessed: Oct. 16, 2019. doi: 10.5897/ĀJAR11.1134.

MAO, H.-L. et al. Effects of Saccharomyces cerevisiae fermentation product on in vitro fermentation and microbial communities of low-quality forages and mixed diets. J. Anim. Sci. v.91, n.7, p.3291-3298, 2013. Available from: <https://academic. oup.com/jas/article-abstract/91/7/3291/4717164>. Accessed: Sep. 23, 2019. doi: $10.2527 /$ jas.2012-5851.
MCCANN, J. C. et al. Induction of subacute ruminal acidosis affects the ruminal microbiome and epithelium. Front. Microbiol., v.7, p.701, 2016. Available from: <https://www.frontiersin.org/ articles/10.3389/fmicb.2016.00701/full>. Accessed: Oct. 23, 2019. doi: 10.3389/fmicb.2016.00701.

MORAN, C. A. Functional components of the cell wall of Saccharomyces cerevisiae: applications for yeast glucan and mannan. In: ANNUAL SYMPOSIUM OF NUTRITIONALBIOTECHNOLOGY IN THE FEED AND FOOD INDUSTRIES, 2004, Nicholasville, USA. Proceedings of Alltech... Nicholasville: Alltech Technical Publications, 2004. p.283-296. Available from: <https://www.hilyses.com/wpcontent/uploads/2016/11/heinrichs-and-Kehoe-2004-pp-194-203. pdf\#page $=271>$. Accessed: Sep. 12, 2019.

NASROLLAHI, S. M. et al. Blood metabolites, body reserves, and feed efficiency of high-producing dairy cows that varied in ruminal $\mathrm{pH}$ when fed a high-concentrate diet. Journal of Dairy Science, v.102, n.1, p.672-677, 2019. Available from: <https:// www.sciencedirect.com/science/article/pii/S0022030218309822>. Accessed: Sep. 9, 2019. doi: 10.3168/jds.2018-15022.

NOCEK, J. E.; HOLT, M. G.; OPPY, J. Effects of supplementation with yeast culture and enzymatically hydrolyzed yeast on performance of early lactation dairy cattle. Journal of Dairy Science, v.94, n.8, p.4046-4056, 2011. Available from: <https://www.sciencedirect.com/science/article/pii/S0022030211004085>. Accessed: Sep. 10, 2019. doi: 10.3168/jds.2011-4277.

Nutrient Requirements of Dairy Cattle (7th rev.), Natl. Acad. Sci., Washington, 2001.

ODENYO, A. A. et al. Effect of multipurpose tree (MPT) supplements on ruminal ciliate protozoa. Animal Feed Science Technology., v.67, n.2-3, p.169-180, 1997. Available from: <https:// www.sciencedirect.com/science/article/pii/S0377840196011182>. Accessed: Sep. 13, 2019. doi: 10.1016/S0377-8401(96)01118-2.

OFEK, I. et al. Adherence of Escherichia coli to human mucosal cells mediated by mannose receptors. Nature, v.265, n.5595, p.623-625, 1977. Available from: <https://www. nature.com/articles/265623a0 $>$. Accessed: Sep. 15, 2019. doi: $10.1038 / 265623 \mathrm{a} 0$.

OLAGARAY, K. E. et al. Effect of Saccharomyces cerevisiae fermentation product on feed intake parameters, lactation performance, and metabolism of transition dairy cattle. Journal of Dairy Science, v.102, n.9, p.8092-8107, 2019. Available from: <https:// www.sciencedirect.com/science/article/pii/S0022030219306186>. Accessed: Sep. 15, 2019. doi: 10.3168/jds.2019-16315.

ÖZTÜRK, H. et al. Effects of hydrolyzed and live yeasts on rumen microbial fermentation in a semicontinuous culture system (Rusitec). Turkish Journal of Veterinary and Animal Sciences, v.39, n.5, p.556-559, 2015. Available from: <https://journals. tubitak.gov.tr/veterinary/abstract.htm?id=17050>. Accessed: Sep. 18, 2019. doi: 10.3906/vet-1506-16.

ROSEMBERGER, G. Exame clínico dos bovinos. 3. ed. Rio de Janeiro. Guanabara Koogan, 1993. 419 p.

RUSSEL J. B.; RYCHLIK J. L. Factors that alter rumen microbial ecology. Science, v.292, n.5519, p.1119-1122, 2001. Available from: <https://science.sciencemag.org/content/292/5519/1119>. Accessed: Oct. 20, 2019. doi: 10.1126/science.1058830. 
SALINAS-CHAVIRA, J. et al. Influence of feeding enzymatically hydrolysed yeast cell wall+ yeast culture on growth performance of calf-fed Holstein steers. Journal of Applied Animal Research, v.46, n.1, p.327-330, 2018. Available from: <https://www.tandfonline.com/doi/full/10.1080/09712119.2017.1299742>. Accessed: Oct. 13, 2019. doi: 10.1080/09712119.2017.1299742.

SCHWEGLER, E. et al. The use of sodic monensin and probiotics for controlling subacute ruminal acidosis in sheep. Brazilian Journal of Veterinary Research and Animal Science, v.51, n.4, p.324-332, 2014. Available from: <https://www.revistas.usp.br/ bjvras/article/view/69502>. Accessed: Oct. 5, 2019. doi: 10.11606/ issn.1678-4456.v51i4p324-339.

SILVA, D. J.; QUEIROZ, A. C. 2002. Análise de alimentos (métodos químicos e biológicos). Viçosa: Universidade Federal de Viçosa. 235p.

STELLA, A. V. et al. Effect of administration of live Saccharomyces cerevisiae on milk production, milk composition, blood metabolites, and faecal flora in early lactating dairy goats. Small Ruminant Research, v.67, n.1, p.7-13, 2007. Available from: <https://www. sciencedirect.com/science/article/pii/S0921448805003585>. Accessed: Oct. 21, 2019. doi: 10.1016/j.smallrumres.2005.08.024.

TABELEÃO, V. C. et al. Influence of monensin and yeast on rumination and metabolic parameters in semi-confined lamb. Acta Scientiarum. Animal Sciences, v.30, n.2, p.181-186, 2008. Available from: <https://www.redalyc.org/ pdf/3031/303126492007.pdf $>$. Accessed: Oct. 29, 2019.

WALLACE, R. John; NEWBOLD, C. James. Probiotics for ruminants. In: Probiotics. Springer, Dordrecht, 1992. p.317-353. Available from: <https://link.springer.com/ chapter/10.1007/978-94-011-2364-8_12>. Accessed: Sep. 3, 2019. doi: 10.1007/978-94-011-2364-8_ 12 .

WALLACE, R. J.; NEWBOLD, C. J. Rumen fermentation and its manipulation: the development of yeast cultures as feed additives. In: Biotechnology in the food industry. Alltech Technical Publications, 1993. p.173-192.

$\mathrm{XU}, \mathrm{C}$, et al. The effect of subacute ruminal acidosis of dairy cows on productivity, digestibility and greenhouse gas emission. J. Agric. Sci. v.8, p.92-100, 2016. Available from: <http://www. ccsenet.org/journal/index.php/jas/article/view/56707>. Accessed: Sep. 15, 2019. doi: 10.5539/jas.v8n4pxx.

YANG, W. Z. et al. Wheat distillers grains in feedlot cattle diets: feeding behavior, growth performance, carcass characteristics, and blood metabolites. J. Anim. Sci, v.90, n.4, p.1301-1310, 2012. Available from: <https://academic.oup.com/jas/articleabstract/90/4/1301/4764616>. Accessed: Oct. 29, 2019. doi: $10.2527 /$ jas.2011-4372.

YUAN, K. et al. Yeast product supplementation modulated feeding behavior and metabolism in transition dairy cows. Journal of Dairy Science, v.98, n.1, p.532-540, 2015. Available from: $<$ https:// www.sciencedirect.com/science/article/pii/S0022030214007978>. Accessed: Oct. 20, 2019. doi: 10.3168/jds.2014-8468.

ZHU, W. et al. Effects of Saccharomyces cerevisiae fermentation products on performance and rumen fermentation and microbiota in dairy cows fed a diet containing low quality forage. Journal of Animal Science and Biotechnology, v.8, n.1, p.36, 2017. Available from: $<$ https://jasbsci.biomedcentral.com/articles/10.1186/s40104017-0167-3>. Accessed: Oct. 16, 2019. doi: 10.1186/s40104-0170167-3. 